Miller, R. A., N. Paprocki, M. J. Stuber, C. E. Moulton, and J. D. Carlisle 2016. Short-eared Owl (Asio flammeus) surveys in the North American Intermountain West: utilizing citizen scientists to conduct monitoring across a broad geographic scale. Avian Conservation and Ecology 11(1):3. http://dx.doi.org/10.5751/ACE-00819-110103

Copyright (C) 2016 by the author(s). Published here under license by the Resilience Alliance.

Research Paper

\title{
Short-eared Owl (Asio flammeus) surveys in the North American Intermountain West: utilizing citizen scientists to conduct monitoring across a broad geographic scale
}

\author{
Robert A. Miller ${ }^{1}$, Neil Paprocki ${ }^{2}$, Matthew J. Stuber ${ }^{3}$, Colleen E. Moulton ${ }^{4}$ and Jay D. Carlisle ${ }^{1}$ \\ ${ }^{1}$ Intermountain Bird Observatory, Boise State University, ${ }^{2}$ HawkWatch International, Inc., ${ }^{3}$ U.S. Fish and Wildlife Service, ${ }^{4}$ Idaho \\ Department of Fish and Game
}

\begin{abstract}
The Short-eared Owl (Asio flammeus) is an open-country species breeding in the northern United States and Canada, and has likely experienced a long-term, range-wide, and substantial decline. However, the cause and magnitude of the decline is not well understood. We set forth to address the first two of six previously proposed conservation priorities to be addressed for this species: (1) better define habitat use and (2) improve population monitoring. We recruited 131 volunteers to survey over 6.2 million ha within the state of Idaho for Short-eared Owls during the 2015 breeding season. We surveyed 75 transects, 71 of which were surveyed twice, and detected Short-eared Owls on 27 transects. We performed multiscale occupancy modeling to identify habitat associations, and performed multiscale abundance modeling to generate a state-wide population estimate. Our results suggest that within the state of Idaho, Short-eared Owls are more often found in areas with marshland or riparian habitat or areas with greater amounts of sagebrush habitat at the 1750 ha transect scale. At the 50 ha point scale, Short-eared Owls tend to associate positively with fallow and bare dirt agricultural land and negatively with grassland. Cropland was not chosen at the broader transect scale suggesting that Short-eared Owls may prefer more heterogeneous landscapes. On the surface our results may seem contradictory to the presumed land use by a "grassland" species; however, the grasslands of the Intermountain West, consisting largely of invasive cheatgrass (Bromus tectorum), lack the complex structure shown to be preferred by these owls. We suggest the local adaptation to agriculture represents the next best habitat to their historical native habitat preferences. Regardless, we have confirmed regional differences that should be considered in conservation planning for this species. Last, our results demonstrate the feasibility, efficiency, and effectiveness of utilizing public participation in scientific research to achieve a robust sampling methodology across the broad geography of the Intermountain West.
\end{abstract}

\section{Recensement de Hiboux des marais (Asio flammeus) dans la région Intramontagnarde Ouest nord- américaine : utilisation de la participation citoyenne pour effectuer un suivi à grande échelle}

RÉSUMÉ. Le Hibou des marais (Asio flammeus), espèce de milieux ouverts nichant dans le nord des États-Unis et au Canada, a vraisemblablement subi une baisse importante de longue date et à grande échelle. Toutefois, la cause et la magnitude de cette baisse ne sont pas bien comprises. Nous avons choisi d'étudier les deux premières de six priorités de conservation proposées antérieurement pour cette espèce : 1) mieux établir l'utilisation de l'habitat; et 2) améliorer le suivi de la population. Nous avons recruté 131 bénévoles pour inventorier plus de 6,2 millions d'ha dans l'État de l'Idaho durant la saison de nidification 2015 du Hibou des marais. Nous avons inventorié 75 transects, dont 71 à deux reprises, et avons détecté le Hibou des marais dans 27 transects. Nous avons effectué une modélisation multiéchelle de sa présence afin de déterminer les associations avec l'habitat et avons réalisé une modélisation multiéchelle de l'abondance afin de générer une estimation de la population à la grandeur de l'État. Nos résultats indiquent que dans l'État de l'Idaho, les Hiboux des marais sont observés le plus souvent dans les secteurs comprenant des marais ou des bandes ripariennes, ou les secteurs qui hébergent de plus grandes quantités d'armoises à l'échelle du transect de 1750 ha. À l'échelle du point de 50 ha, les hiboux avaient tendance à montrer une association positive avec les terres agricoles en jachère et au sol nu, et une association négative avec les prairies. Les terres cultivées n'étaient pas choisies à l'échelle du transect, laissant croire que ce hibou préfère peut-être des paysages plus hétérogènes. De prime abord, nos résultats peuvent sembler contradictoires pour ce qui est de l'utilisation de l'habitat par une espèce « de prairie »; cependant, les prairies de la région Intramontagnarde Ouest, surtout composées de brome (Bromus tectorum) envahissant, n'ont pas la structure complexe que semble préférer ce hibou. Nous avançons que l'adaptation locale à l'agriculture représente le deuxième meilleur habitat après leur préférence historique au milieu naturel. Néanmoins, nous avons confirmé la présence de différences régionales qui devraient être prises en compte dans la planification de la conservation de cette espèce. Enfin, nos résultats montrent la faisabilité, l'efficacité et l'efficience de l'utilisation de la participation citoyenne dans la recherche scientifique afin d'obtenir une méthodologie d'échantillonnage robuste dans la vaste région Intramontagnarde Ouest.

Key Words: abundance; habitat; Idaho; land use; occupancy; population trend; road survey 


\section{INTRODUCTION}

The Short-eared Owl (Asio flammeus) is a global open-country species often occupying tundra, marshes, grasslands, and shrublands (Holt et al. 1999, Wiggins et al. 2006). In North America, the Short-eared Owl breeds in the northern United States and Canada, mostly wintering in the United States and Mexico (Wiggens et al. 2006). Swengel and Swengel (2014) surveyed seven midwestern states, finding Short-eared Owls breeding in larger intact patches of grassland ( $>500$ ha) with heavy plant litter accumulation, and little association with shrub cover. However, habitat use has not been thoroughly explored within the Intermountain West of North America.

Booms et al. (2014) argued that the Short-eared Owl has experienced a long-term, range-wide, substantial decline in North America. To support their claim they summarize Breeding Bird Survey and Christmas Birds Count results from across North America (National Audubon Society 2012, Sauer et al. 2014). Figure 1 illustrates the general downward trend in Short-eared Owl populations in western North America between 1966 and 2013, as estimated from the Breeding Bird Survey; however, only California and Saskatchewan had sufficient sample size for a significant result (Sauer et al. 2014). Booms et al. (2014) acknowledge that neither the Breeding Bird Survey nor Christmas Bird Count adequately sample the Short-eared Owl population in North America because the species is not highly vocal and is most active during crepuscular periods and at night, resulting in very few detections.

Fig. 1. State and province estimated annual trends in Shorteared Owl (Asio flammeus) populations from 1966-2013 from the Breeding Bird Surveys within the United States and Canada (Sauer et al. 2014). California and Saskatchewan are the only samples whose $95 \%$ confidence interval failed to overlap zero.

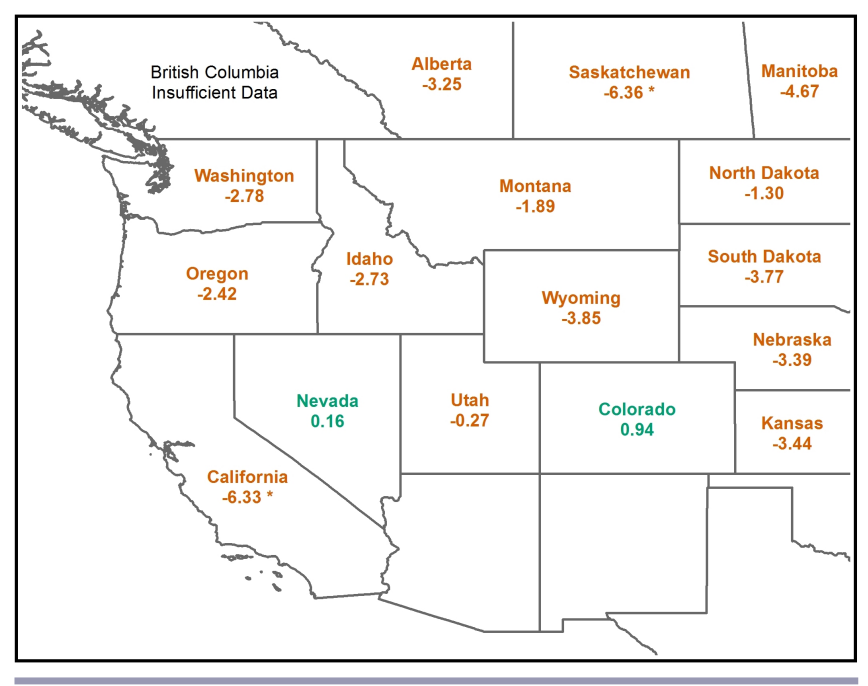

Langham et al. (2015) used Breeding Bird Survey data, Christmas Bird Count data and correlative distribution modeling with various future emission scenarios, to predict distribution shifts of North American bird species in response to future climate change. Their results predict that $90 \%$ of the winter range of Short-eared
Owls in the year 2000 may no longer be occupied by 2080 and, even with a northward shift in winter range, the total area of winter range is expected to reduce in size by $34 \%$ (National Audubon Society 2014).

Booms et al. (2014) and Langham et al. (2015) have highlighted the apparent disconnect of current and predicted population trends of Short-eared Owls and current conservation priorities. Booms et al. (2014) proposed six measures to better understand and prioritize actions associated with the conservation of this species. We have chosen to focus on the first two of those measures: (1) better define and protect important habitats; and (2) improve population monitoring (Booms et al. 2014).

Public participation in scientific research, sometimes referred to as citizen science, can take many forms ranging from contributory to contractual (Shirk et al. 2012). Public participation in scientific research has a long history of contributing data critical to the monitoring of wildlife, e.g., Breeding Bird Surveys (Sauer et al. 2014), Christmas Birds Counts (National Audubon Society 2012), eBird data for conservation (Callaghan and Gawlik 2015), and Monarch Butterfly monitoring (Ries and Oberhauser 2015). Public participation projects can deliver benefits to multiple constituents including the volunteers and the lead researchers. For a contributory project, the volunteer gains increased content knowledge, improved science inquiry skills, appreciation of the complexity of ecosystems and ecosystem monitoring, and increased technical monitoring skills (Shirk et al. 2012). The primary advantage to the researcher for a contributory project is at the project scale, such as decreased cost, increased sample size, and geographical spread (Shirk et al. 2012).

We set forth to address the first two conservation actions for Short-eared Owls as promoted by Booms et al (2014), specifically defining habitat needs and improving population monitoring in the Intermountain West. Our program objectives included: (1) to identify the habitat use by Short-eared Owls during the breeding season in the Intermountain West; (2) to establish a baseline population estimate to be used to evaluate population trends; (3) to develop a monitoring framework to evaluate population trends over time; and (4) evaluate if these objectives can be met by using a large network of citizen science volunteers through contributory public participation in a scientific research framework as described by Shirk et al. (2012).

\section{METHODS}

\section{Study area}

Our study area included the state of Idaho within the Intermountain West of the United States. We stratified this region by first laying a $10 \mathrm{~km}$ by $10 \mathrm{~km}$ grid over the entire state. We quantified presumed Short-eared Owl habitat within our study area using GAP data (U.S. Geological Survey 2011). Grassland, shrubland, marshland/riparian, and agriculture land cover classes were considered to be potential Short-eared Owl habitat (Wiggins et al. 2006). Grids with at least $70 \%$ land cover consisting of any of these four classes were considered in our survey stratum. All other grids were removed. The result consisted of 6.28 million ha within the stratum, primarily in southern and westcentral Idaho (Fig. 2). 
Fig. 2. Distribution of strata (blue squares) and spatially balanced survey transects (black squares) for Short-eared Owl (Asio flammeus) surveys during the 2015 breeding season across the state of Idaho within the Intermountain West of the United States.

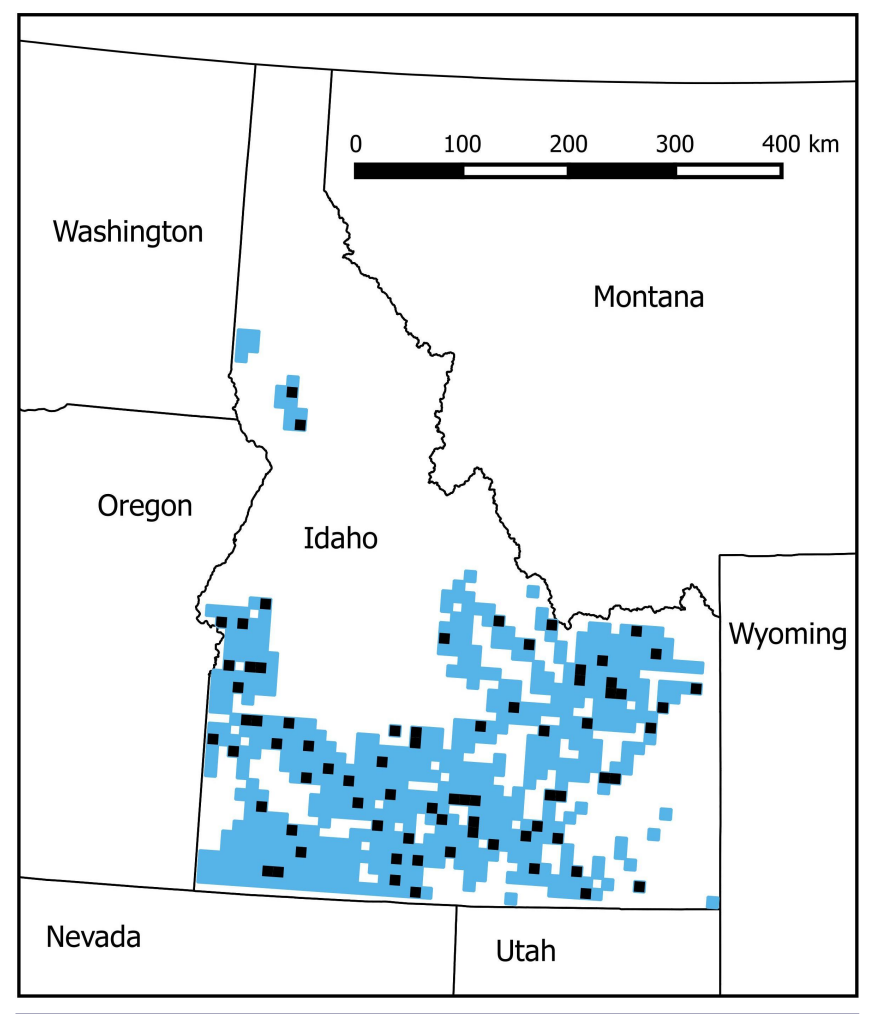

\section{Transect selection}

We selected survey transects within the stratum using a spatially balanced sample of $10 \mathrm{~km}$ by $10 \mathrm{~km}$ grids using a Generalized Random-Tessellation Stratified (GRTS) process (Stevens and Olsen 2004). We eliminated grids with no secondary roads, a requirement of our road-based protocol. We selected a spatially balanced sample of 82 grids to correspond to the number of volunteers (Fig. 2). We delineated a survey route within each grid along a $9 \mathrm{~km}$ stretch of secondary road, the maximum survey length feasible using the protocol and our justification for choosing a $10 \mathrm{~km}$ by $10 \mathrm{~km}$ grid structure (Larson and Holt 2016). If multiple possible routes were available within a single grid, we chose routes expected to have the least traffic, routes on the edge of the greatest amount of roadless habitat, or routes with the highest likelihood of detecting Short-eared Owls (a potential source of bias discussed later). Larson and Holt (2016) report that in favorable conditions Short-eared Owls can be correctly identified up to $1600 \mathrm{~m}$ away, with high detectability up to $800 \mathrm{~m}$. Calladine et al. (2010) had a mean initial detection distance of $500-700 \mathrm{~m}$, with a maximum recorded value of $2500 \mathrm{~m}$. Because our analysis method is robust for false negative detections, but less so for false positive detections, we chose to assume a larger average initial detection distance of $1 \mathrm{~km}$. Therefore we considered all land within $1 \mathrm{~km}$ of the surveyed points as sampled habitat.

\section{Public participation recruitment}

We recruited citizen science volunteers to complete survey routes. We used a combination of partnerships, social media, and personal contacts to complete our roster. Our most successful recruiting tool was to reach out to existing volunteer organizations such as naturalist groups and birding groups, electronically, through submitted newsletter articles, and in person. In some cases we reached out to professional biologists to cover remote grids or grids on restricted lands, e.g., reservation lands or national laboratory lands closed to the public.

We began recruiting volunteers two months prior to the beginning of the survey window. Within two weeks we had recruited volunteers for 45 of the surveys. Volunteers for the remaining grids trickled in over the following four weeks as new contacts were established and logistics regarding restricted grids were finalized. Roughly two-thirds of our volunteers were true citizen scientists, whereas one-third were professional biologists either volunteering to survey routes or assigned to complete the route, e.g., restricted lands. The difference between the originally selected number of grids and those successfully surveyed was the result of six volunteers failing to complete the survey (essentially a random sample of missed surveys) and one survey that did not meet the minimum quality requirements.

We provided training materials, e.g., owl identification, a procedure manual, and datasheets to volunteers to help ensure survey quality. We asked volunteers to submit data via an online portal, but also accepted written datasheet submission.

\section{Owl surveys}

Observers attempted to complete two surveys per transect, one survey in March and one survey in April. We asked volunteers to separate the two visits by at least one week. Observers surveyed points separated by approximately a half mile $(800 \mathrm{~m})$ along secondary roads from 100 to 10 minutes prior to local civil twilight, completing as many points as possible ( $8-11$ points) during the 90 minute span (Larson and Holt 2016). The multiscale analysis methods we used relax the assumption of point independence enabling the intermediate point spacing with overlapping area surveyed, i.e., $800 \mathrm{~m}$ spacing instead of $2000 \mathrm{~m}$.

At each point observers performed a five-minute point count, noting each individual bird minute by minute. For each observation of a Short-eared Owl, observers recorded whether the bird was seen, heard (hoots, barks, screams, wing clip, bill snap), or both, and what behaviors were observed (perched, foraging, direct flight, agonistic, courtship).

\section{Vegetation data}

At each point observers collected basic habitat data in both March and April as we expected some land cover to change during that period, e.g., agricultural field may have been plowed from stubble to dirt between visits. Observers noted the proportion of habitat within $400 \mathrm{~m}$ of the point (half the distance between points) that consisted of shrubland, grassland, marshland, fallow agriculture, retained stubble agriculture, plowed dirt agriculture, and green agriculture (new green plant growth visible; Table 1).

We collected transect level data using Geographic Information System (GIS) analysis by buffering all surveyed points by $1 \mathrm{~km}$, the presumed average maximum detection distance, and quantifying the proportion of each habitat type from the 2005 
Table 1. Definition, variable name used in models, mean, standard deviation (SD), range, position within multiscale hierarchy, and source of covariates evaluated for influence in occupancy and abundance analysis of Short-eared Owls (Asio flammeus) within Idaho during the 2015 breeding season.

\begin{tabular}{|c|c|c|c|c|c|}
\hline Variable & Name in Models & Mean \pm SD & Range & Hierarchy & Source \\
\hline Day of year & julian & $90 \pm 18$ & $59-119$ & Detection & Surveyor \\
\hline Minutes before civil twilight & stime & $61 \pm 31$ & $2-140$ & Detection & Surveyor \\
\hline Proportion shrub within $400 \mathrm{~m}$ & shrub & $0.38 \pm 0.39$ & $0.00-1.00$ & Point-scale Availability & Surveyor \\
\hline Proportion grass within $400 \mathrm{~m}$ & grass & $0.19 \pm 0.29$ & $0.00-1.00$ & Point-scale Availability & Surveyor \\
\hline Proportion marsh within $400 \mathrm{~m}$ & marsh & $0.01 \pm 0.03$ & $0.00-1.00$ & Point-scale Availability & Surveyor \\
\hline Proportion fallow ag within $400 \mathrm{~m}$ & fallow & $0.03 \pm 0.13$ & $0.00-1.00$ & Point-scale Availability & Surveyor \\
\hline Proportion stubble ag within $400 \mathrm{~m}$ & stubble & $0.05 \pm 0.17$ & $0.00-1.00$ & Point-scale Availability & Surveyor \\
\hline Proportion dirt ag within $400 \mathrm{~m}$ & dirt & $0.08 \pm 0.21$ & $0.00-1.00$ & Point-scale Availability & Surveyor \\
\hline Proportion green ag within $400 \mathrm{~m}$ & green & $0.10 \pm 0.23$ & $0.00-1.00$ & Point-scale Availability & Surveyor \\
\hline Proportion sagebrush within $1 \mathrm{~km}$ & Sageland & $0.42 \pm 0.35$ & $0.00-1.00$ & Occupancy/Abundance & GIS (Shrubmap) \\
\hline Proportion steppe within $1 \mathrm{~km}$ & Steppeland & $0.24 \pm 0.28$ & $0.00-1.00$ & Occupancy/Abundance & GIS (Shrubmap) \\
\hline Proportion shrubland within $1 \mathrm{~km}$ & Shrubland & $0.45 \pm 0.35$ & $0.00-1.00$ & Occupancy/Abundance & GIS (Shrubmap) \\
\hline Proportion grassland within $1 \mathrm{~km}$ & Grassland & $0.12 \pm 0.18$ & $0.00-0.75$ & Occupancy/Abundance & GIS (Shrubmap) \\
\hline Proportion cropland within $1 \mathrm{~km}$ & Cropland & $0.36 \pm 0.37$ & $0.00-1.00$ & Occupancy/Abundance & GIS (Shrubmap) \\
\hline Proportion marshland within $1 \mathrm{~km}$ & Marshland & $0.02 \pm 0.05$ & $0.00-0.38$ & Occupancy/Abundance & GIS (Shrubmap) \\
\hline
\end{tabular}

ShrubMap dataset (Table 1; Hanser et al. 2005). We used the ShrubMap dataset instead of GAP because we discovered local quality issues with the GAP dataset that produced spurious results during the analysis phase.

\section{Statistical analysis}

We performed both multiscale occupancy modeling (Nichols et al. 2008, Pavlacky et al. 2012) and multiscale abundance modeling (Chandler et al. 2011; R. A. Sparks, D. C. Pavlacky, and D. J Hanni, unpublished manuscript). For multiscale occupancy modeling we implemented a minute-by-minute replacement design, allowing for simultaneous evaluation of detection, pointscale occupancy, and transect-scale occupancy (Nichols et al. 2008). Similar to Pavlacky et al. (2012) we used a modified version of Nichols et al. (2008) where the point-scale occupancy uses spatial replicates, but unlike Pavlacky et al. (2012) we also included our temporal replicates, i.e., two visits, essentially producing a model where the $\Theta$ parameter represents a combination of pointscale occupancy and point-scale availability.

For the multiscale abundance analysis we implemented a modified, open population, $N$-mixture model with a Poisson distribution (Chandler et al. 2011; R. A. Sparks, D. C. Pavlacky, and D. J Hanni, unpublished manuscript). Similar to the occupancy modeling, we deviated from Chandler et al. (2011) by utilizing spatial replicates for point-scale occupancy (R. A. Sparks, D. C. Pavlacky, and D. J Hanni, unpublished manuscript), along with our temporal replicates producing a model where the $\Phi$ parameter represents a combination of point-scale occupancy and pointscale availability. Both analysis methods are robust to missing data, allowing us to include surveys with differing numbers of points $(8-11)$ and the four transects that were only surveyed once.

Within each analysis approach we evaluated variables influencing the probability of detection (day of year and minutes before civil twilight), availability at the point scale (vegetation values collected by observers within $400 \mathrm{~m}$ of point, $\sim 50 \mathrm{ha}$ ), and transect occupancy or abundance (habitat types collected through GIS data within $1 \mathrm{~km}$ of all sampled points; Table 1$)$. The $10 \mathrm{~km}$ by
$10 \mathrm{~km}$ grid structure was only used to distribute and spatially balance the transects; all analyses only utilized the 1750 ha area surrounding the points actually surveyed ( $1 \mathrm{~km}$ radius buffer).

We used a sequential, parameter-wise model building strategy (Lebreton et al. 1992, Doherty et al. 2012), ranking models using Akaike Information Criterion adjusted for small sample size $\left(\mathrm{AIC}_{\mathrm{c}}\right)$ for the occupancy modeling and quasi-Akaike Information Criterion adjusted for small sample size $\left(\mathrm{QAIC}_{\mathrm{c}}\right)$ for abundance modeling because our count data was overdispersed (Burnham and Anderson 2002, Richards 2008). For each type of multiscale modeling (occupancy and abundance), we first evaluated each variable by assessing the null model, the model with just the variable of interest, and the model with the variable of interest and the square of the variable of interest. We eliminated the variable from further consideration if the null model ranked highest, otherwise we propagated forward the highest ranking of the variable of interest or the variable and it's square. We first selected candidate variables influencing the probability of detection $(p)$ by considering all combinations of the retained variables and chose all variables appearing in models within two $\triangle \mathrm{AIC}_{\mathrm{c}}$ or $\triangle \mathrm{QAIC}_{\mathrm{c}}$ of the top model. We then fixed the variable set for probability of detection and repeated the procedure for variables influencing the occupancy/availability at the point-scale $(\Theta$ [for occupancy modeling], $\Phi$ [for abundance modeling]). Last, we repeated the procedure for variables influencing transect occupancy $(\Psi)$ or transect abundance $(\Lambda)$ to arrive at our final model set for each analysis.

For inference we used model averaging of all models falling within two $\triangle \mathrm{AIC}_{\mathrm{c}}$ or $\triangle \mathrm{QAIC}_{\mathrm{c}}$ of the top model that also ranked higher than the null model (Burnham and Anderson 2002). For each variable appearing within this final model set, we created and present model averaged predictions by ranging the variable of interest over its measured range while holding all other variables at their mean value. From the occupancy models we created an occupancy prediction map across our strata using only the transect-scale data, i.e., the only stratum-wide data available. For all abundance reporting we inflated the confidence intervals by 
the variance inflation factor $(\hat{c})$ to account for measured overdispersion (Richards 2008). For the state-wide abundance estimate we extrapolated the estimated average transect abundance from our top model set, back to the total area of our sampled stratum.

We present graphical representations of estimated effect size with $95 \%$ confidence intervals to align with the majority of scientific literature, whereas, we present abundance estimates with $80 \%$ confidence intervals to more closely align with local management objectives. We conducted all statistical analyses in Program R and Program Mark (White and Burnham 1999, R Core Team 2015). We used the R package "RMark" to interface between Program $\mathrm{R}$ and Program Mark for the multiscale occupancy modeling (Laake 2014). We used the R package "unmarked" to perform the multiscale abundance modeling (Fiske and Chandler 2011). We used R package "AICcmodavg" to calculate the variance inflation factor $(\hat{c})$, to rank all models (calculating $\mathrm{AIC}_{\mathrm{c}}$ and $\mathrm{QAIC}_{\mathrm{c}}$ ), and to perform model averaging (Mazerolle 2015).

\section{RESULTS}

A total of 131 volunteers participated in the survey portion of the program, contributing 1010 volunteer hours of their time, and travelling 16,000 miles to complete the surveys. We successfully surveyed 75 grids, 71 of which were surveyed twice. We detected Short-eared Owls on 21 and 26 transects during the first and second round of surveys, respectively, resulting in detections on a total of 27 transects with the two survey visits. We detected Short-eared Owls during both visits on 20 of the transects.

The model selection process for the multiscale occupancy analysis produced six models falling within two $\Delta \mathrm{AIC}_{\mathrm{c}}$ of the top model (Table 2). Day-of-year (julian) was selected in all models positively influencing the probability of detection of at least one Short-eared Owl, given that at least one owl was present (Table 2, Fig. 3). The proportion of land within $400 \mathrm{~m}(\sim 50 \mathrm{ha})$ of the survey point covered in fallow agriculture, plowed dirt agriculture, and grass were all selected influencing the probability of at least one Shorteared Owl at a point, given that at least one owl occupied the transect (Table 2, Fig. 4). Fallow agriculture and plowed dirt

Table 2. Top model set, and the null model for comparison (in bold), for multiscale occupancy analysis predicting the occupancy of transects within Idaho by Short-eared Owls (Asio flammeus) during the 2015 breeding season. $\mathrm{k}$ is the number of parameters in the model, AICc is Akaike's Information Criterion adjusted for small sample size, $\triangle \mathrm{AICc}$ is the difference in AICc values between individual models and the top model, and $\mathrm{w}_{\mathrm{i}}$ is the model weight. We only presented models where $\triangle \mathrm{AICc} \leq 2.00$, the set used to generate model averaged predictions, and the null model for comparison.

\begin{tabular}{lcccc}
\hline \hline Model & $\mathrm{k}$ & $\mathrm{AIC}_{c}$ & $\Delta \mathrm{AIC}_{c}$ & $\mathrm{w}_{\mathrm{i}}$ \\
\hline$\Psi(.) \Theta() p.($ julian$)$ & 4 & 1067.94 & 0.00 & 0.29 \\
$\Psi(.) \Theta($ dirt $) p($ julian$)$ & 5 & 1068.92 & 0.98 & 0.18 \\
$\Psi($ Sageland) $\Theta() p.($ julian$)$ & 5 & 1069.12 & 1.18 & 0.16 \\
$\Psi(.) \Theta($ fallow) $p($ julian$)$ & 5 & 1069.44 & 1.50 & 0.13 \\
$\Psi($ Marshland $\Theta() p.($ julian$)$ & 5 & 1069.50 & 1.56 & 0.13 \\
$\Psi(.) \Theta($ grass $) p($ julian$)$ & 5 & 1069.78 & 1.84 & 0.11 \\
$\Psi(.) \Theta(.) \mathbf{p}()$. & $\mathbf{3}$ & $\mathbf{1 0 7 8 . 3 6}$ & $\mathbf{1 0 . 4 2}$ & --- \\
\hline
\end{tabular}

agriculture had a positive relationship, and grass a negative relationship with availability. The proportion of land within $1 \mathrm{~km}$ $(\sim 1750 \mathrm{ha})$ of all surveyed points on a transect in sagebrush or marshland/riparian habitat were each selected within the top model set, but each appeared in only a subset of the models (Table 2, Fig. 5). Both sagebrush and marshland/riparian habitat were positively associated with transect occupancy. Applying the top model set across the full state stratum, we created a prediction map illustrating the areas of highest potential for occupancy by Short-eared Owls (Fig. 6).

Fig. 3. Model averaged prediction generated from multiscale occupancy top model set for the effect size of day-of-year on the probability of detecting at least one Short-eared Owl (Asio flammeus) at a point given that there is at least one Short-eared Owl at the point during the 2015 breeding season. Black line = model prediction; green area $=95 \%$ confidence interval.

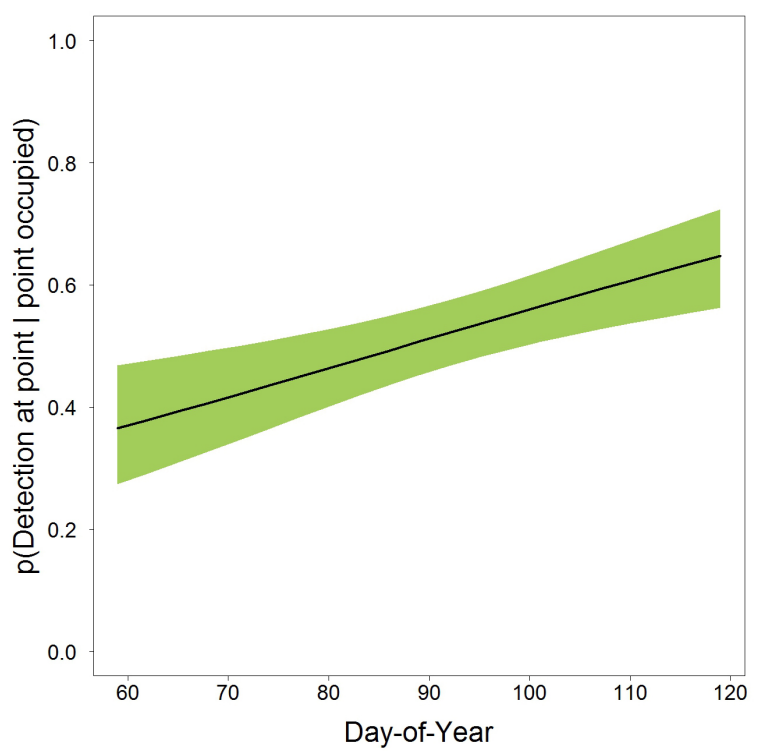

Fig. 4. Model averaged predictions generated from multiscale occupancy top model set for the effect size of the proportion of area within $400 \mathrm{~m}$ of surveyed point in (a) fallow agriculture; (b) plowed dirt agriculture; and (c) grass, influencing the availability of at least one Short-eared Owl (Asio flammeus) at the point to be sampled given that the transect was occupied by at least one Short-eared Owl during the 2015 breeding season. Black line = model prediction; green area $=95 \%$ confidence interval.
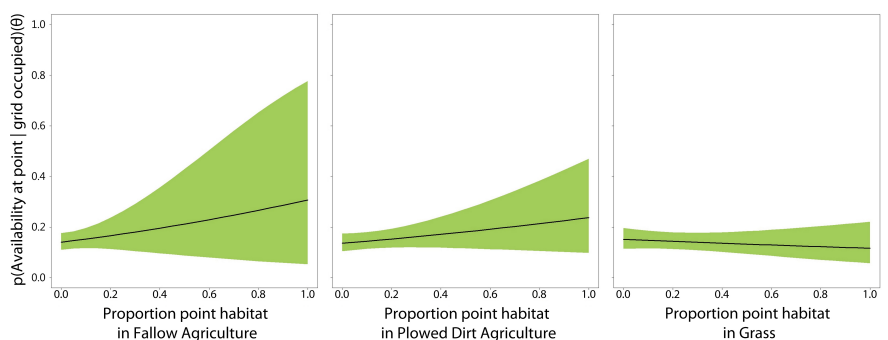

in Grass 
Fig. 5. Model averaged predictions generated from multiscale occupancy top model set for the effect size of the proportion of the area within $1 \mathrm{~km}$ of surveyed points in (a) sageland; and (b) marshland or riparian habitat influencing the probability of occupancy of the full transect by at least one Short-eared Owl (Asio flammeus) during the 2015 breeding season. Black line $=$ model prediction; green area $=95 \%$ confidence interval.
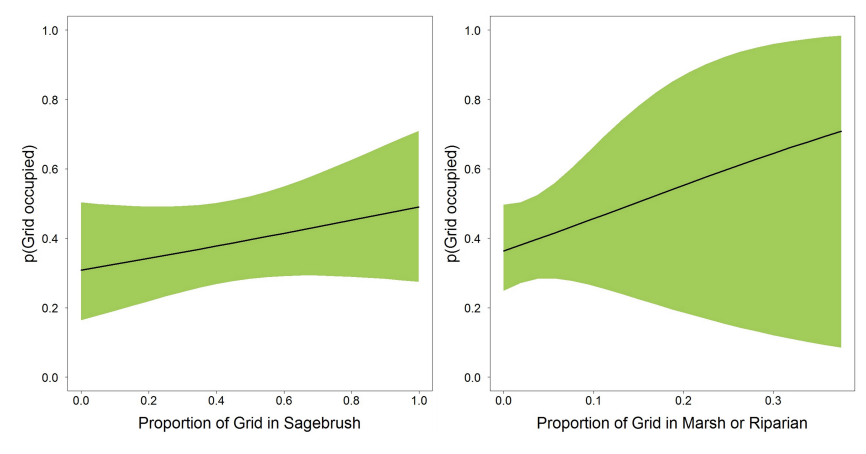

Fig. 6. Model averaged prediction generated from multiscale occupancy top model set based on the proportion of original $10 \mathrm{~km} \times 10 \mathrm{~km}$ grids in sageland and marshland/riparian habitat influencing the probability of occupancy by at least one Short-eared Owl (Asio flammeus) during the 2015 breeding season. Color scales represent $(\Psi)$ from light orange (0.33) to dark red (0.46).

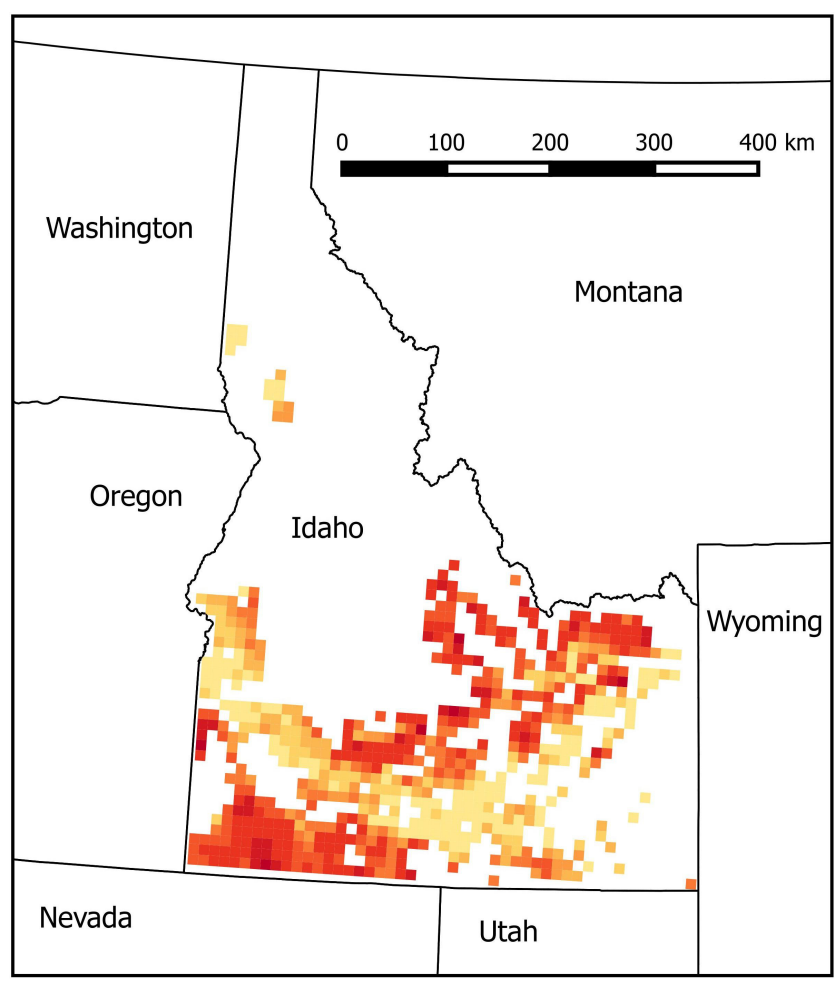

The model selection process for the multiscale abundance analysis produced 16 models falling within two $\Delta$ QAIC $_{\mathrm{c}}$ of the top model (Table 3). However, the top ranking model was the null model suggesting no or very weak influence, or insufficient sample size to detect an influence, of the measured parameters on abundance. We therefore do not present covariate predictions for abundance. The probability of detection $(p)$ for the abundance model was 0.43 (95\% confidence interval: $0.31-0.54)$. The probability of pointscale availability $(\Phi)$ was 0.09 (95\% confidence interval: $0.06-$ $0.14)$. The calculated abundance per transect $(\Lambda)$ from the top model was $0.82(95 \%$ confidence interval: $0.52-1.28)$. Using the top model (null) from the multiscale abundance modeling, we extrapolated estimated transect abundance back to the area of the state stratum to estimate a total of 2615 adult Short-eared Owls in Idaho (80\% confidence interval: 1953 - 3501).

Table 3. Top model set, and the null model for comparison (in bold), for multiscale abundance analysis predicting the abundance of Short-eared Owls (Asio flammeus) on grids within Idaho during the 2015 breeding season. $\mathrm{k}$ is the number of parameters in the model, QAICc is quasi-Akaike's Information Criterion adjusted for small sample size, $\triangle$ QAICc is the difference in QAICc values between individual models and the top model, and $\mathrm{w}_{\mathrm{i}}$ is the model weight. We only presented models where $\Delta$ QAICc $\leq$ 2.00 .

\begin{tabular}{|c|c|c|c|c|}
\hline Model & $\mathrm{k}$ & $\mathrm{QAIC}_{c}^{\dagger}$ & $\Delta$ QAIC $_{c}$ & $\mathrm{w}_{\mathrm{i}}$ \\
\hline$\Lambda(.) \Phi(.) \mathbf{p}()$. & 4 & 640.59 & 0.00 & 0.11 \\
\hline$\Lambda($ Grassland $) \Phi() p.()$. & 5 & 640.71 & 0.12 & 0.10 \\
\hline$\Lambda($ Sageland $) \Phi() p.()$. & 5 & 640.90 & 0.31 & 0.09 \\
\hline$\Lambda($ Shrubland) $\Phi() p.()$. & 5 & 641.27 & 0.68 & 0.08 \\
\hline$\Lambda$ (Steppeland) $\Phi() p.()$. & 5 & 641.52 & 0.93 & 0.07 \\
\hline$\Lambda(.) \Phi() p.($ julian $)$ & 5 & 641.58 & 0.99 & 0.07 \\
\hline$\Lambda($ Grassland $) \Phi() p.($ julian $)$ & 6 & 641.76 & 1.17 & 0.06 \\
\hline$\Lambda($ Grassland + Sageland $) \Phi() p.()$. & 6 & 641.76 & 1.17 & 0.06 \\
\hline$\Lambda$ (Sageland) $\Phi() p.($ julian $)$ & 6 & 641.94 & 1.35 & 0.05 \\
\hline$\Lambda($ Sageland + Shrubland $) \Phi() p.()$. & 6 & 642.00 & 1.41 & 0.05 \\
\hline$\Lambda$ (Grassland + Shrubland $) \Phi() p.()$. & 6 & 642.01 & 1.42 & 0.05 \\
\hline$\Lambda($ Grassland + Steppeland $) \Phi() p.()$. & 6 & 642.09 & 1.50 & 0.05 \\
\hline$\Lambda$ (Shrubland) $\Phi() p.($ julian $)$ & 6 & 642.31 & 1.72 & 0.05 \\
\hline$\Lambda($ Savanna $) \Phi() p.()$. & 5 & 642.53 & 1.94 & 0.04 \\
\hline$\Lambda($ Cropland $) \Phi() p.()$. & 5 & 642.54 & 1.95 & 0.04 \\
\hline$\Lambda($ Steppeland $) \Phi() p.($ julian $)$ & 6 & 642.58 & 1.99 & 0.04 \\
\hline
\end{tabular}

\section{DISCUSSION}

We successfully engaged a large group of volunteers to survey for Short-eared Owls across a broad geographic region in the Intermountain West. The analysis identified important Shorteared Owl habitat associations, providing insight into which habitats in the region may be most important for conservation and further study. The large scale over which we were able to survey helped us to produce the first rigorous state-wide population estimate for the species in Idaho, directly informing the state's State Wildlife Action Planning (SWAP) process.

The multiscale occupancy analysis enabled us to explore the factors influencing the occupancy of the transect as a whole, and if the transect was occupied, in which point habitats the birds were present (Pavlacky et al. 2012). Within Idaho we found that 
transects with increased amounts of marshland/riparian or increased sagebrush as the primary habitat types had higher likelihood of Short-eared Owl presence. Marshland is not widely available in our study area, but where it does occur, owls were often detected. Marshland and riparian areas generally present more structural complexity, more plant diversity, and may thus present higher prey availability, which in turn could attract Shorteared Owls for breeding.

We found Short-eared Owl occupancy at the transect scale to be influenced by sagebrush habitat, but not grassland habitat, which may be unexpected because in many parts of its range the Shorteared Owl is considered a grassland species (Clark 1975, Holt et al. 1999, Swengel and Swengel 2014). However, much of the Intermountain West has been converted to invasive cheatgrass (Bromus tectorum) and other invasive annual plants (West 2000). Swengel and Swengel (2014) note that in the Midwest Short-eared Owls most often nest in large areas of contiguous grassland, with heavy litter or "rough grassland." The structure of the grassland in their study is quite different from the more homogenous, low litter grass found in invasive grasslands in the Intermountain West. Short-eared Owls in other studies appear to occur less often in landscapes similar to the invasive grasslands of the west (Clark 1975, Fondell and Ball 2004). Sagebrush habitats in Idaho usually provide more structural complexity than local grasslands, which may explain the association of the owls with this land-cover type in our area.

Given that a transect was occupied, Short-eared Owls were more likely to occupy points with fallow or bare dirt agriculture, and less likely to occupy points with grassland. Fallow agriculture may provide more of the habitat structure preferred by Short-eared Owls than the invasive grasslands in our study area, and the unique plant composition within fallow agriculture may result in increased prey availability (Moulton et al. 2006). The association with other agricultural stages may be related to prey availability as well, but could also be the result of recent changes in the landscape after the owls settled in the area, i.e., owls settled when fields were fallow, but stayed when plowed to dirt and green plants began to grow. The higher use of agricultural lands in relation to nonagricultural lands within a transect could be the result of local adaptation to agriculture, or the result of habitat degradation occurring in the nonagricultural landscape as a result of the cheatgrass invasion or open lands grazing (West 2000, Fondell and Ball 2004). Because our surveys were limited to roads and many of the roads were built to support agriculture, we may not have adequately sampled undisturbed natural habitat (Gelbard and Belnap 2003), which is becoming increasingly rare in the region. Although agriculture was selected at the point scale, cropland was not chosen at the transect scale suggesting that Short-eared Owls are inhabiting more heterogeneous landscapes within our study area than pure agriculture.

Our abundance modeling failed to select any habitat associations influencing abundance. We expect this is the result of the abundance model being generally less powerful in detecting these associations than occupancy models, the low density of Shorteared Owls on the landscape resulting from territoriality, and that our data was overdispersed. The integration of the variance inflation factor to account for overdispersion tends to favor less complex models (Richards 2008). However, we were still able to successfully utilize the null model to generate our state-wide abundance prediction.

Our study had a number of potential sources of bias, which was one reason we performed both occupancy and abundance analyses. The abundance analysis is more sensitive to sources of bias than the occupancy analysis, but most of these biases do apply to both analysis types. Potential sources of bias that could have increased our estimates included placement of the survey route along the best habitat within the grid, misidentifying species, e.g., counting a Long-eared Owl (Asio otus) as a Short-eared Owl, identifying owls further than $1 \mathrm{~km}$ from the survey point, and sampling fledglings instead of only counting adults. We were aware of two fledging groups within our study area during the survey window, however we do not believe any were counted during a survey. Potentially biasing our results lower included not detecting birds less than $1 \mathrm{~km}$ because of obstructions or local landscape relief, not sampling the areas that fell outside of our stratum, e.g., grids with only $68 \%$ of target habitat instead of $>$ $70 \%$ target habitat, and the potential influence of road-based surveys. Roads represent fragmented landscapes that have been shown to have a negative association for Short-eared Owls in the Midwest (Swengel and Swengel 2014). Additionally, Short-eared Owls may be negatively affected by road noise (e.g., Ware et al. 2015).

This project was only viable with the generous support of our volunteer base. However, the volunteer base was likely the largest variance introduced to our project. The skill set of our volunteers ranged from expert to beginner. We emphasized training during the project, but volunteers were not evaluated on their skills, a process more often performed on professional surveys. In fact, one transect was omitted because it was clear the minimum expectations were not achieved. However, checking datasheets for quality and completeness confirmed that most of our volunteers were very diligent in completing the assigned tasks. The biggest unknown we had pertained to the correct identification of Shorteared Owls. We provided training materials for proper identification and emphasized to volunteers to only record owls that they were certain were Short-eared Owls, because our methods were robust to false negative observations, but less robust to false positive observations. Within our study area, the Longeared Owl would be the most likely species to confuse with a Shorteared Owl. We focused on the distinction within our training materials. Unfortunately, we did not ask the volunteers to count Long-eared Owls or to record "possible" Short-eared Owls; a modification we will make going forward. As with most programs, quantifying the magnitude of the bias from each factor is often not feasible. We do believe that these biases have been managed as best as possible within the program and that the actual population size falls well within our confidence intervals.

We were successful in meeting all of our initial objectives utilizing a largely volunteer labor force. We suggest that the use of a distributed volunteer labor force resulted in greater efficiency in survey coverage, resulted in more surveys completed, and ultimately resulted in a higher quality inference than would have occurred using only professional staff. In subsequent years we expect to continue the use of citizen scientist volunteers, and maintain the basic structure of the initial 2015 pilot program. We expect to expand the surveys to two states in 2016 (Idaho and 
Utah) and eight states in 2017, by completing at least 40 transects per state and maintaining a state-based stratum within the overall analysis to identify local habitat differences and generate stateby-state estimates of abundance. We expect to narrow the sampling window to decrease the chance of sampling fledging groups that possibly biased our 2015 results, and shift the sampling window with elevation to ensure access to higher elevation sites. The earliest sampling window for Idaho will be 1 March through 15 April for sites below $4000 \mathrm{ft}$ in elevation, shifting to 1 April through 15 May for site above $6000 \mathrm{ft}$ in elevation. Last, we expect to refine the habitat model to collect more specific habitat data at each point.

\section{CONCLUSION}

We successfully recruited a large group of volunteers to sample a broad geography within the Intermountain West for Short-eared Owls during the 2015 breeding season. Our results have identified specific habitat associations, confirming that habitat use may vary regionally. We have established abundance estimates for Idaho that will act as a baseline for further studies to identify and quantify any trends that may be occurring in the population. We have confirmed that our study design was sufficient to meet our objectives and will only require minor modifications moving forward. We are actively working to expand this successful program to other states within the breeding range of the Shorteared Owl.

Responses to this article can be read online at: http://www.ace-eco.org/issues/responses.php/819

\section{Acknowledgments:}

We are deeply grateful for all of the volunteers that invested their time and money to complete the surveys described in this paper. We thank the many volunteer organizations that helped us recruit eager volunteers, including Boise State University, Friends of Deer Flat Wildlife Refuge, Golden Eagle Audubon Society, Idaho Bird Conservation Partnership, Idaho Birders Linked Electronically, Idaho Birding, Idaho Master Naturalists, National Audubon Society, Portneuf Valley Audubon Society, Prairie Falcon Audubon Society, Snake River Audubon Society, and the Southwest Idaho Birders Association. We thank the agencies, tribes, and private companies that also contributed effort to coordinate and in some cases survey routes, including Gonzales-Stoller Surveillance, Idaho Department of Fish and Game, Idaho Department of Parks and Recreation, Idaho National Laboratory, U.S. National Park Service, Shoshone Bannock Tribes, U.S. Bureau of Land Management, U.S. Fish and Wildlife Service, and U.S. Forest Service. We thank Travis Booms for the encouragement and consultation to initiate this project. We thank Matt Larson and Denver Holt of the Owl Research Institute for consultation on the survey protocol. We thank Rob Sparks and David Pavlacky of the Bird Conservancy of the Rockies for their consultation on the statistical analysis. Lastly, we thank the Intermountain Bird Observatory and Hawkwatch International for their in-kind support of the authors' time to design, organize, analyze, and report these results.

\section{LITERATURE CITED}

Booms, T. L., G. L. Holroyd, M. A. Gahbauer, H. E. Trefry, D. A. Wiggins, D. W. Holt, J. A. Johnson, S. B. Lewis, M. D. Larson, K. L. Keyes, and S. Swengel. 2014. Assessing the status and conservation priorities of the Short-eared Owl in North America. Journal of Wildlife Management 78:772-778. http://dx.doi. org/10.1002/jwmg.719

Burnham, K., and D. Anderson. 2002. Model selection and multimodel inference: a practical information-theoretic approach. Second Edition. Springer-Verlag, New York, New York, USA.

Calladine, J., G. Garner, C. Wernham, and N. Buxton. 2010. Variation in the diurnal activity of breeding Short-eared Owls Asio Flammeus: implications for their survey and monitoring. Bird Study 57:89-99. http://dx.doi.org/10.1080/00063650903437503

Callaghan, C. T., and D. E. Gawlik. 2015. Efficacy of eBird data as an aid in conservation planning and monitoring. Journal of Field Ornithology 86:298-304. http://dx.doi.org/10.1111/jofo.12121

Chandler, R. B., J. A. Royle, and D. I. King. 2011. Inference about density and temporary emigration in unmarked populations. Ecology 92:1429-1435. http://dx.doi.org/10.1890/10-2433.1

Clark, R. J. 1975. A field study of the Short-Eared Owl, Asio flammeus (Pontoppidan), in North America. Wildlife Monographs 47:3-67.

Doherty, P. F., G. C. White, and K. P. Burnham. 2012. Comparison of model building and selection strategies. Journal of Ornithology 152:317-323. http://dx.doi.org/10.1007/s10336-010-0598-5

Fiske, I., and R. Chandler. 2011. Unmarked: an R package for fitting hierarchical models of wildlife occurrence and abundance. Journal of Statistical Software 43:1-23. http://dx.doi. org/10.18637/jss.v043.i10

Fondell, T. F., and I. J. Ball. 2004. Density and success of bird nests relative to grazing on western Montana grasslands. Biological Conservation 117:203-213. http://dx.doi.org/10.1016/ S0006-3207(03)00293-3

Gelbard, J. L., and J. Belnap. 2003. Roads as conduits for exotic plant invasions in a semiarid landscape. Conservation Biology 17:420-432. http://dx.doi.org/10.1046/j.1523-1739.2003.01408.x

Hanser, S. E., S. T. Knick, J. Hak, and J. Kagan. 2005. Current distribution of sagebrush and associated vegetation in the Columbia Basin and southwestern regions. NatureServe, Arlington, Virginia, USA. [online] URL: http://sagemap.wr.usgs.gov/Shrubmap.aspx

Holt, D. W., R. Berkley, C. Deppe, P. L. Enriquez-Rocha, P. D. Olsen, J. L. Petersen, J. L. Rangel-Salazar, K. P. Segars, and K. L. Wood. 1999. Strigidae species accounts. Pages 153-242 in J. del Hoyo, A. Elliott, and J. Sargatal, editors. Handbook of the birds of the world. Volume 5. Lynx, Barcelona, Spain.

Laake, J. L. 2014. RMark: an R interface for analysis of capturerecapture data with MARK. AFSC Processed Report 2013-01. Alaska Fisheries Science Center, Seattle, Washington, USA.

Langham, G. M., J. G. Schuetz, T. Distler, C. U. Soykan, and C. Wilsey. 2015. Conservation status of North American birds in the face of future climate change. PLOS ONE 10(9):e0135350. http:// dx.doi.org/10.1371/journal.pone. 0135350 
Larson, M. D., and D. W. Holt. 2016. Using roadside surveys to detect Short-eared Owls: a comparison of visual and audio techniques. Wildlife Society Bulletin 40(2), in press.

Lebreton, J. D., K. P. Burnham, J. Clobert, and D. R. Anderson. 1992. Modeling survival and testing biological hypotheses using marked animals: a unified approach with case studies. Ecological Monographs 62:67-118.

Mazerolle, M. J. 2015. AICcmodavg: model selection and multimodel inference based on $(Q) A I C(c)$. R package version: 2.0-3. R Foundation for Statistical Computing, Vienna, Austria. [online] URL: http://CRAN.R-project.org/package=AICcmodavg

Moulton, C. E., R. S. Brady, and J. R. Belthoff. 2006. Association between wildlife and agriculture: underlying mechanisms and implications in Burrowing Owls. Journal of Wildlife Management 70:708-716. http://dx.doi.org/10.2193/0022-541X(2006)70[708: ABWAAU]2.0.CO;2

National Audubon Society. 2012. The Christmas bird count historical results. National Audubon Society, New York, New York, USA. [online] URL: http://netapp.audubon.org/CBCObservation/ Historical/ResultsBySpecies.aspx?1

National Audubon Society. 2014. Climate endangered Short-eared Owl. The Audubon climate report. National Audubon Society, New York, New York, USA. [online] URL: http://climate. audubon.org/birds/sheowl/short-eared-owl

Nichols, J. D., L. L. Bailey, A. F O’Connell Jr., N. W. Talancy, E. H. C. Grant, A. T. Gilbert, E. M. Annand, T. P. Husband, and J. E. Hines. 2008. Multi-scale occupancy estimation and modeling using multiple detection methods. Journal of Applied Ecology 45:1321-1329. http://dx.doi.org/10.1111/j.1365-2664.2008.01509. $\mathrm{x}$

Pavlacky Jr., D. C., J. A. Blakesley, G. C. White, D. J. Hanni, and P. M. Lukacs. 2012. Hierarchical multi-scale occupancy estimation for monitoring wildlife populations. Journal of Wildlife Management 76:154-162. http://dx.doi.org/10.1002/ jwmg. 245

R Core Team. 2015. R: a language and environment for statistical computing. R Foundation for Statistical Computing, Vienna, Austria. [online] URL: http://www.R-project.org/

Richards, S. A. 2008. Dealing with overdispersed count data in applied ecology. Journal of Applied Ecology 45:218-227. http://dx. doi.org/10.1111/j.1365-2664.2007.01377.x

Ries, L., and K. Oberhauser. 2015. A citizen army for science: quantifying the contributions of citizen scientists to our understanding of monarch butterfly biology. BioScience 65:419-430. http://dx.doi.org/10.1093/biosci/biv011

Sauer, J. R., J. E. Hines, J. E. Fallon, K. L. Pardieck, D. J. Ziolkowski, Jr., and W. A. Link. 2014. The North American breeding bird survey, results and analysis 1966-2013. Version
01.30.2015. USGS Patuxent Wildlife Research Center, Laurel, Maryland, USA. [online] URL: http://www.mbr-pwrc.usgs.gov/ bbs/bbs.html

Shirk, J. L., H. L. Ballard, C. C. Wilderman, T. Phillips, A. Wiggins, R. Jordan, E. McCallie, M. Minarchek, B. V. Lewenstein, M. E. Krasny, and R. Bonney. 2012. Public participation in scientific research: a framework for deliberate design. Ecology and Society 17(2):29. http://dx.doi.org/10.5751/ ES-04705-170229

Stevens Jr., D. L., and A. R. Olsen. 2004. Spatially balanced sampling of natural resources. Journal of the American Statistical Association 99:262-278. http://dx.doi.org/10.1198/016214504000000250

Swengel, S. R., and A. B. Swengel. 2014. Short-eared Owl abundance and conservation recommendations in relation to site and vegetative characteristics, with notes on Northern Harriers. Passenger Pigeon 76:51-68.

U.S. Geological Survey. 2011. National gap analysis program (GAP). May 2011. Land cover data portal, Version 2. USGS GAP, Boise, Idaho, USA. [online] URL: http://gapanalysis.usgs. gov/gaplandcover/

Ware, H. E., C. J. W. McClure, J. D. Carlisle, and J. R. Barber. 2015. A phantom road experiment reveals traffic noise is an invisible source of habitat degradation. Proceedings of the National Academy of Sciences 112:12105-12109. http://dx.doi. org/10.1073/pnas. 1504710112

West, N. E. 2000. Synecology and disturbance regimes of sagebrush steppe ecosystems. Pages 15-26 in P. G. Entwistle, A. M. DeBolt, J. H. Kaltenecker, and K. Steenhof, editors. Proceedings: sagebrush steppe ecosystems symposium June 21-23, 1999 Boise, Idaho USA. U.S. Bureau of Land Management publication no. BLM/ID/PT-001001+1150, Boise, Idaho, USA.

White, G. C., and K. P. Burnham. 1999. Program MARK: survival estimation from populations of marked animals. Bird Study 46: S120-S138. http://dx.doi.org/10.1080/00063659909477239

Wiggins, D. A., D. W. Holt and S. M. Leasure. 2006. Short-eared Owl (Asio flammeus). In A. Poole, editor. The birds of North America online. Cornell Lab of Ornithology, Ithaca, New York, USA. [online] URL: http://bna.birds.cornell.edu/bna/species/062
Editor-in-Chief: Keith A.Hobson Subject Editor: André Desrochers
Sponsored by the Society of Canadian Ornithologists and Bird Studies Canada Parrainée par la Société des ornithologistes $d u$ Canada et Etudes d'oiseaux Canada

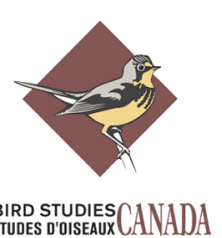

